\title{
切削条件と被削材成分を考虜した 工具摩耗予測システムの開発*
}

\author{
赤 澤 浩 一** 尾 崎 勝 彦** 社 本 英 二*** \\ Development of a System to Predict tool Wear Considering Cutting Conditions and Workpiece Components
}

Koichi AKAZAWA, Katsuhiko OZAKI and Eiji SHAMOTO

\begin{abstract}
The present study presents a practical system to predict tool wear considering cutting conditions and workpiece components. The proposed system is developed for automation of production processes, optimization of cutting conditions, development of new workpiece materials, etc. The system consists of tool temperature analysis and tool wear prediction. The tool temperature is simulated by FEM analysis, and then the tool wear is predicted by utilizing the simulated temperature. The tool wear prediction model has a few constants which need to be identified for each set of tool and workpiece materials. The constants are identified and the material properties are measured for steel workpiece and a carbide tool, and the system is verified by some experiments in the present research.
\end{abstract}

Key words: tool wear, tool temperature, FEM analysis, cutting conditions, workpiece components

\section{1. 緒言}

現在, 機械加工生産の主流を占める多品種中·少量生産に おいては，少品種多量生産に比べ生産工程の自動化が遅れ， その自動化, 高能率化が望まれている. 生産工程の自動化, 高能率化を阻害する要因は様々であるが, その一つに工具 摩耗があげられる。加工により工具摩耗が進行すると, 工 具刃先丸みの増大に伴う仕上げ面粗さの増加，および刃先 の減退による加工誤差が生じる. また極度に摩耗した工具 による切削は, 過大な切削抵抗を生じ, 工具および工作物 を損傷する可能性があり危険である.こうしたことから工 具摩耗量の予測は, 切削条件の最適化や工程の自動化にお いて重要な技術であると考えられる. 一方, 鉄鋼材料に対 するニーズは多様であり, 切削工具寿命もその一つにあげ られる。材料開発において工具摩耗予測技術は, 試作・実 験回数の削減につながり, 材料開発のスピードアップに貢 献できる。 また, 工具摩耗に及ぼす材料特性について理解 が深まることによって新しい材料開発への指針が得られる ことも大いに期待される.

これまでに, 工具摩耗の予測技術についていくつか研究 成果が報告されている 1) 4). しかしながら，これらの予測 には工具刃先の温度が既知である必要があり, 実際の加工 条件設計や被削材の材料開発などに利用されている例は少 ない. そこで本研究では, これまでに提案されている工具 摩耗モデルを改良するとともに, 有限要素法解析による刃 先温度の予測を組み合わせることで, 少ない実験デー夕を 基に工具摩耗を予測する実用的なシステムの開発を行った。

\section{2. 工具摩耗モデル}

工具摩耗の機構としては, 主に, 被削材に含まれる硬質 粒子によって機械的に工具刃先が削り取られるアブレシブ

$*$ 原稿受付 平成 20 年 4 月 9 日

** 正 会 員 (株)神戸製鋼所（神戸市西区高塚台 1-5-5）

*** 正 会 員 名古屋大学 (名古屋市千種区不老町)
摩耗と, 高温・高圧環境下で工具材成分が被削材中に拡散 することで摩耗が進展する拡散摩耗があげられる。拡散摩 耗は切削温度に影響を指数的に受けることが知られており。 次(1)のようなモデルが提案されている 2 .

$$
d W=A_{1} \cdot \sigma \cdot d L \cdot \exp \left(-A_{2} / \text { temp }\right)
$$

ここで, $d W$ は摩耗量の増分であり, $d L$ は切削距離の増分を 示している. また， $\sigma$ と temp はそれぞれ工具刃先近傍の応 力と切削温度を表している. 式(1)はフィックの拡散方程式 と類似の形式となっている ${ }^{2)}$ こから, その妥当性が理解で きる.

本研究では, 式(1)の拡散摩耗モデルに新たにアブレシブ 摩耗モデルを統合し, 幅広い切削条件下で工具逃げ面摩耗 の予測が可能な工具摩耗予測モデルとして, 次式で表され るモデルを提案する.

$$
d W=d L \cdot C_{1} \cdot H_{w} / H_{t}+d L \cdot C_{2} \cdot \exp \left(-C_{3} / \text { temp }\right)
$$

本モデルは第 1 項がアブレシブ摩耗のモデル, 第 2 項が拡 散摩耗モデルとなっている。 ここで, $H_{w}$ は被削材の切削温 度条件下での硬さ, $H_{t}$ は工具材の切削温度条件下での硬さ を表している. $C_{1}$ はアブレシブ摩耗の影響係数であり, 被 削材に含まれる硬質介在物（ $\mathrm{TiN}, \mathrm{TiC}, \mathrm{Al}_{2} \mathrm{O}_{3}, \mathrm{SiO}_{2}$ など）の 含有率に依存すると考えられる， $C_{2}, C_{3}$ は拡散摩耗の影響 係数であり，ともに切削試験により同定される.ここで, 工具逃げ面のアブレシブ摩耗は, 図 1 に示すように, 仕上 げ面側の被削材に含まれるアブレシブ粒子が工具刃先に押 し付けられ, 工具材が除去される摩耗である.ここでアブ レシブ粒子は十分に硬いとすると, アブレシブ摩耗量はア ブレシブ粒子が工具材に押し込まれる量に比例し, さらに その押し込み量は工具材の硬さに反比例するものと考えら れる。一方, 被削材は工具刃先から逃げ面にかけて塑性変 形と若干の弾性変形を受けながら流れていく，つまり，こ の 3 次塑性域では被削材は常に塑性変形状態であることか ら，表面付近のアブレシブ粒子は切削条件等に関係なく， 


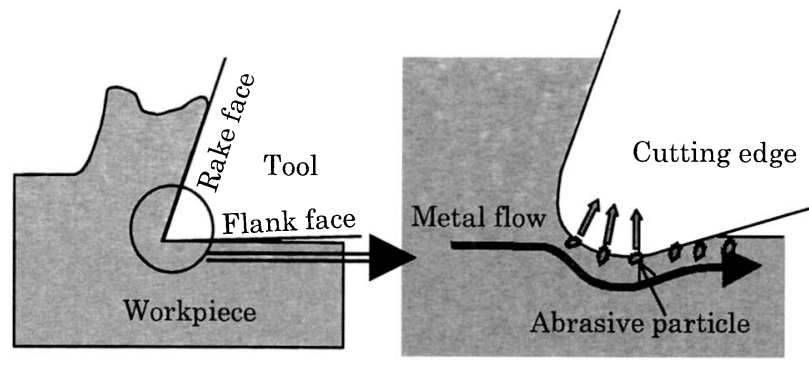

Fig. 1 Abrasive wear mechanism

切削温度下における被削材の硬さに対応する圧力で工具材 に押し込まれていると考えられる，以上をまとめると，ア ブレシブ摩耗量は, 被削材の硬さに比例し, 工具材の硬さ に反比例するものと考えられ, 式(2)の第 1 項のように表さ れる。

なお，アブレシブ摩耗はその機構から切削温度の影響を あまり受けず，低速切削条件域から高速切削条件域まで大 きく変化しないと言われているが, 実際には本モデルの第 1 項で表されるように, 工具材と被削材の硬さの温度依存性 によって切削速度の影響を受けると考えられる。

\section{3. 実 験 方 法}

\section{1 切削実験方法}

本研究では, 外周旋削加工により工具摩耗のデー夕取得を行 った. 工具には超硬 P10 種 SNMG120405((株)タンガロイ製 TX10D)を使用し，工具ホルダ(住友電工ハードメタル(株)製 PSBN-R) に取り付けて加工を行った. 加工機械にはオークマ (株)製 NC 旋盤 LS30-Nを使用した。 また，被削材としては，構 造用炭素鋼 S45C（Hv:216MPa）を用い, 乾式切削を行った. 切 削条件については, 切削温度を大きく変化させるため, 切削速 度を 5 段階に変化させた. 切削条件を表 1 に示す.

\section{2 被削材および工具材の硬さの測定方法}

アブレシブ摩耗の予測に必要な切削温度下における被削材の 硬さ情報としては，硬さと強い相関を持つ降伏応力を圧縮試験 により測定した值を使用した．試験片の形状は，直径 $9 \mathrm{~mm}$, 高 さ $12 \mathrm{~mm}$ とし, 圧縮速度は $0.005 \mathrm{~mm} / \mathrm{s}$ とした. 測定装置は島津 製作所製オートグラフを使用した。一方，工具材のビッカース 硬さの測定は, 日本光学 (株) 製高温硬さ試験装置 (高温顕微 硬度計 $\mathrm{QM}$ 型) により実施した. 測定にはサファイア $\left(\alpha-\mathrm{Al}_{2} \mathrm{O}_{3}\right)$ の圧子を使用した. 測定条件を表 2 に示す.

\section{3 切削温度の解析方法}

工具刃先の切削温度は，工具摩耗予測モデルにおいて重要な 入力パラメータである. 切削温度の測定に関しては, これまで に工具一被削材熱電対法や, 赤外線式非接触温度計を用いて輻 射熱を測定する方法などが報告されているが ${ }^{5,6)}$. 広範囲の切削 条件や被削材成分に対して測定を行うことは実用的ではない. そこで本研究では, 切削温度データベースの構築が容易に行え るよう市販の温度連成 FEM 解析ソフト (伊藤忠テクハソリュー ションズ社製 ADVANT EDGE 2D）を使用し，本ソフトウエア より計算される工具刃先温度を前述の摩耗予測モデルの入力值 とする. 解析条件として, 被削材強度の温度依存性は前節にて述 べた高温圧縮試験により得られたデー夕を用いる. その他の解析 条件を表 3 に示す. 実際の旋削加工は工具のノーズ部での切削な ど, 複雑な切削断面形状となるが, 本研究ではまず, 比較的 2 次 元切削に近いと考えられる旋削工具の直線切れ刃部の工具摩耗を 対象としたため, 2 次元切削の解析を行うことができる本ソフト
Table 1 Cutting conditions

\begin{tabular}{ll}
\hline Cutting speed & $50,100,150,200,250 \mathrm{~m} / \mathrm{min}$ \\
Feed rate & $0.25 \mathrm{~mm} / \mathrm{rev}$ \\
Depth of cut & $1.5 \mathrm{~mm}$ \\
\hline
\end{tabular}

Table 2 Conditions for hardness measurements

\begin{tabular}{ll}
\hline Test tempareture & $\mathrm{RT}, 300,600,700,800^{\circ} \mathrm{C}$ \\
Test load & $9.8 \mathrm{~N}$ \\
Atmosphere & Vacuum $\left(3.0 \times 10^{-\mathrm{s}}\right.$ torr $)$ \\
Loading time & $30 \mathrm{~s}$ \\
Heating rate & $0.333^{\circ} \mathrm{C} / \mathrm{s}$ \\
Hold time & $300 \mathrm{~s}$
\end{tabular}

Table 3 Conditions for analysis of cutting temperature

\begin{tabular}{ll}
\hline Rake angle & $-5^{\circ}$ \\
Relief angle & $5^{\circ}$ \\
Radius of cutting edge roundness & $0.01 \mathrm{~mm}$ \\
Thermal conductivity of workpiece & $45 \mathrm{~W} / \mathrm{m} \cdot{ }^{\circ} \mathrm{C}$ \\
Specific heat of workpiece & $460 \mathrm{~J} / \mathrm{kg} \cdot{ }^{\circ} \mathrm{C}$ \\
Density of workpiece & $7900 \mathrm{~kg} / \mathrm{m}^{3}$ \\
Cutting length & $10 \mathrm{~mm}$ \\
Friction coefficient & 0.5 \\
\hline
\end{tabular}

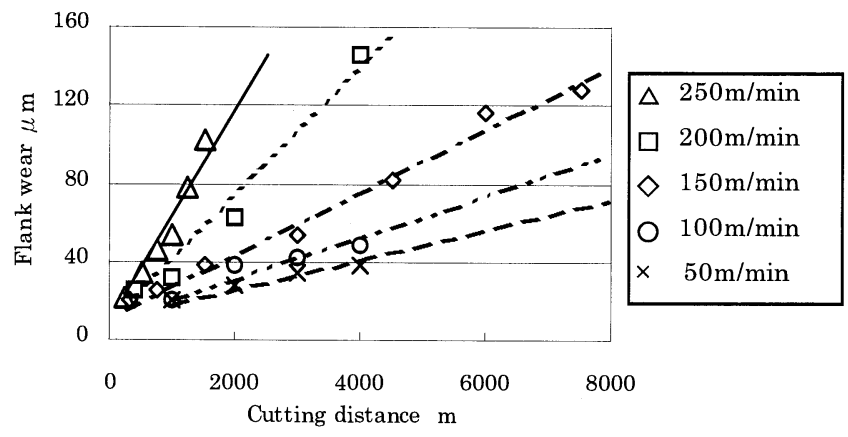

Fig. 2 Relationship between cutting speed and tool wear

ウエアを使用した.

\section{4. 実 験 結 果}

切削実験結果として, 各切削速度における工具逃げ面摩耗幅 と切削距離の関係を図 2 に示す. 図に示されるように, 超硬工 具による S45C 鋼の旋削加工では, 切削速度が $150 \mathrm{~m} / \mathrm{min}$ 以上の 比較的高速度領域では切削速度の増加にともなって工具摩耗量 が急激に増加するのに対して, $150 \mathrm{~m} / \mathrm{min}$ 以下の中低速度領域で は高速度領域と比較して切削速度の影響が小さい. 高速度領域 での切削速度増加に対する工具摩耗量の大きな増加は, 拡散摩 耗が切削速度に対して指数関数的に増大するためであると考え られる. 一方, 低速度領域では, 工具摩耗の主要因がアブレシ ブ摩耗であり, 拡散摩耗がほとんど起こっていないため, 切削 速度の影響が小さいと考えられる.

次に, 切削プロセスのシミュレーションによる工具内部温度 の解析結果の 1 例として, 切削速度 $200 \mathrm{~m} / \mathrm{min}$ における工具刃 先部の温度分布を図 3 に示す. 本研究では逃げ面の摩耗を対象 とするため, すくい面上の最高温度部ではなく, 図中に○で示 している刃先部の温度を切削温度とした. 切削速度と切削温度 解析值の関係を図 4 に示す. 切削温度の解析值の妥当性につい

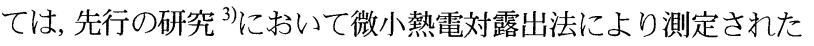




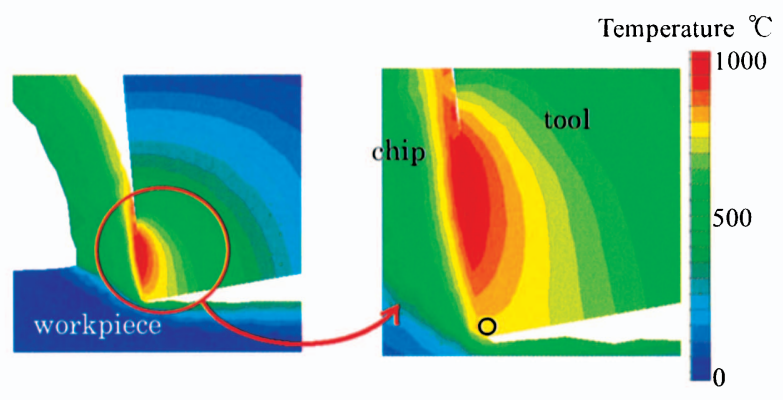

Fig. 3 Simulated temperature distribution

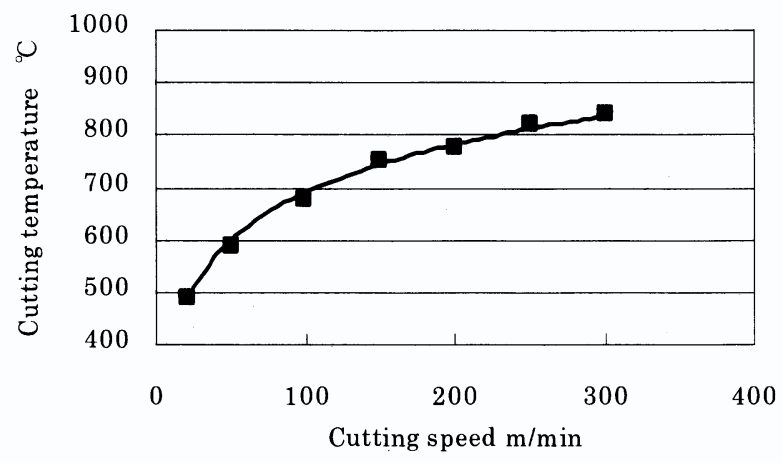

Fig. 4 Relationship between cutting speed and cutting temperature

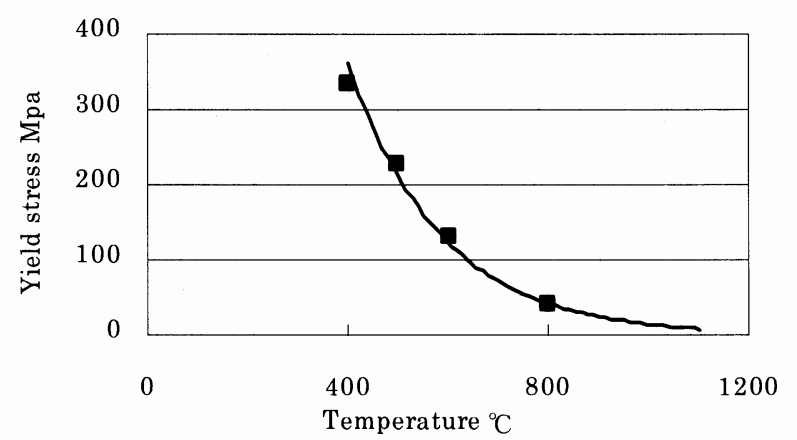

Fig. 5 Relationship between temperature and yield stress of workpiece

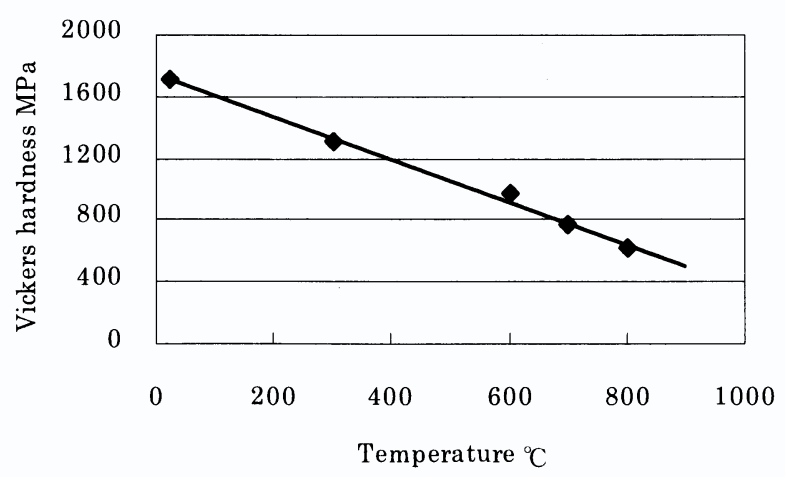

Fig. 6 Relationship between temperature and Vickers hardness of tool material

值と比較を行った. 測定では, 炭素鋼 S48C を切削速度 $100 \mathrm{~m} / \mathrm{min}$, 送り速度 $0.15 \mathrm{~mm} / \mathrm{rev}$ においてすくい面上の最高温度が約 $830^{\circ} \mathrm{C}$ となっており，S45Cにおける同一切削条件における最高温度の 解析值は $809^{\circ} \mathrm{C}$ であることから, 実際の現象に即した解析が行え ていると考えられる.

被削材の高温時における降伏応力と工具材の高温時における ビッカース便さをそれぞれ図 5, 図 6 に示す. 図から, 実験に使 用した被削材および工具材は，共に温度の増加にともなって軟

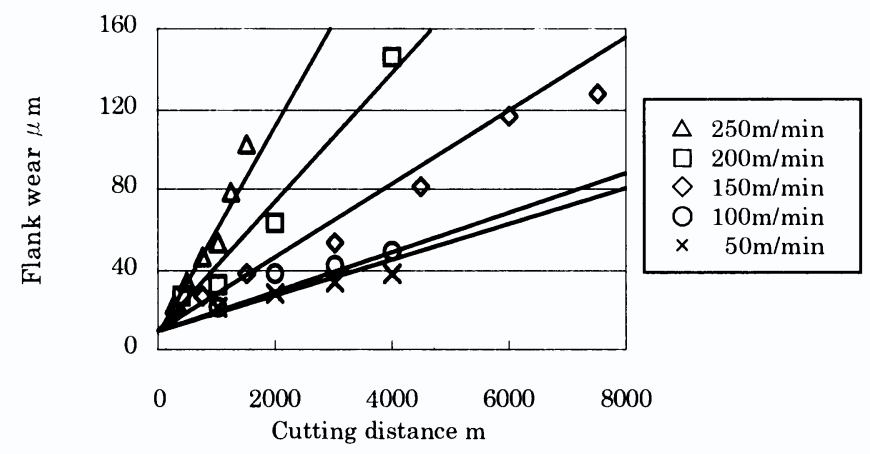

Fig. 7 Comparison between calculated and measured flank wear

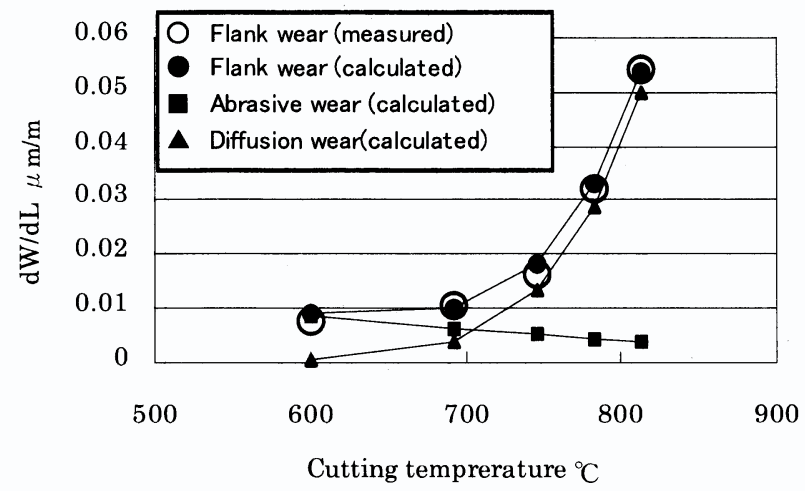

Fig. 8 Comparison between calculated and measured wear rates $d W / d L$

化するが, 被削材の軟化傾向の方が工具材と比較して大きいこ とが分かる．このことから，アブレシブ摩耗は切削速度の変化 ：対し一定量となるのではなく，切削温度の上昇にともなって 忘少少するものと推測される.

式(2)に示す工具摩耗予測モデルにより，工具摩耗量を予測す るためには, 切削温度 temp, 被削材の高温降伏応力 $H_{w}$, 工具の 高温硬さ $H_{t}$ が必要となる. 切削温度については解析により求め ることができる．また，高温時の被削材の降伏応力および工具 の硬さについては，切削温度と同一温度において測定試験を行 い，デー夕を取得することが理想であるが，この場合，予め切 削温度を知っておく必要があり, 現実的には困難である. そこ で，図 5, 図 6 に示す代表的な温度条件にて測定を行った実験デ 一夕から回帰式を求め, 切削温度における值を算出することと した. 回帰式を式(3)および式(4)に示す. 式(3), 式(4)を用いるこ とにより，少ない実験回数で, 簡便に被削材の降伏応力および 工具材の硬さを求めることが可能となる. また，工具逃げ面と 被削材仕上げ面の微小接触領域では両者の温度は同じと考えら れることから, 本研究では, 前述の解析により得られた切削温 度を工具, 被削材の温度とした。

$$
\begin{aligned}
H_{w} & =3110 \cdot \exp (-0.00538 \cdot \text { temp }) \\
H_{t} & =-1.38 \cdot \text { temp }+1740
\end{aligned}
$$

次に, 各切削速度における切削温度 temp, 被削材の降伏応力 $H_{w}$, および工具材の硬さ $H_{t}$ を算出し, 実際の工具逃げ面摩耗の 測定值とモデルによる計算值が一致するように, モデル係数 $C_{1}$, $C_{2}, C_{3}$ の最適化を実施した. その結果, $C_{1}$ は $0.0641, C_{2}$ は 114000 , $C_{3}$ は 11900 となった．このモデル係数により，逃げ面摩耗幅を 算出した結果を図 7 に示す。 なお，今回実験に使用した工具に は初期刃先丸みが逃げ面側から観察すると $10 \mu \mathrm{m}$ 程度存在して いたため, 初期摩耗として逃げ面摩耗幅の計算結果に $10 \mu \mathrm{m}$ を 
Table 4 Cutting conditions for temperature simulation

\begin{tabular}{ll}
\hline Cutting speed & $20,50,100,150,200,250,300 \mathrm{~m} / \mathrm{min}$ \\
Feed rate & $0.10,0.25,0.40 \mathrm{~mm} / \mathrm{rev}$ \\
\hline
\end{tabular}

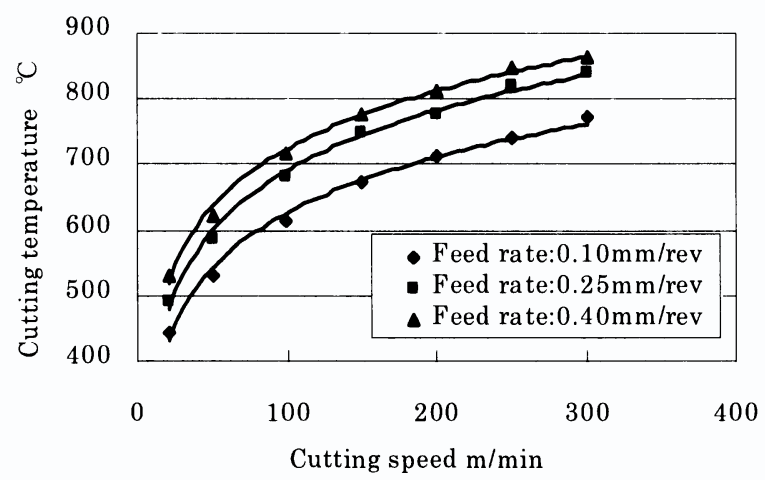

Fig. 9 Relationship between cutting conditions and cutting temperature (S45C)

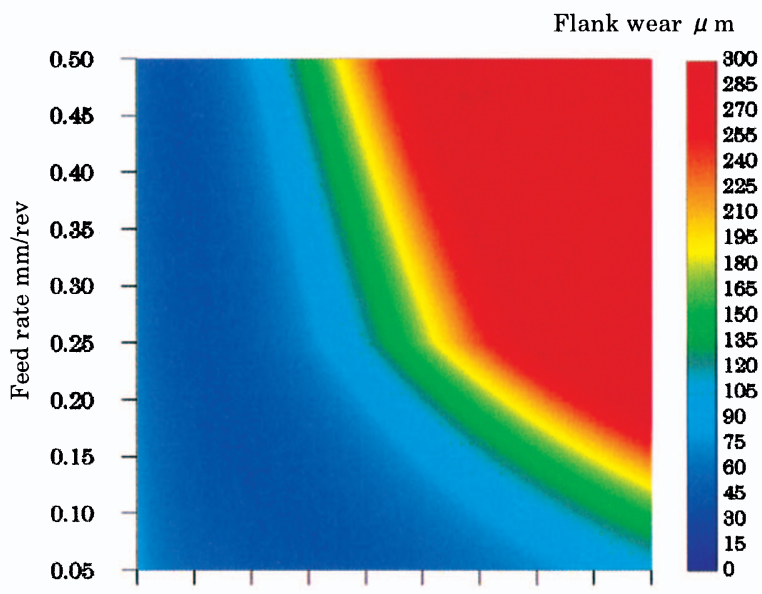

$\begin{array}{llllllllll}20 & 60 & 100 & 140 & 180 & 220 & 280 & 300 & 340 & 380\end{array}$ Cutting speed $\mathrm{m} / \mathrm{min}$

Fig. 10 Relationship between cutting conditions and predicted flank wear (S45C)

加えることとした．図から分かるように，各切削速度における 逃げ面摩耗量と工具摩耗予測モデルによる計算值は良く一致し ており，各モデル係数は適切に同定されていると考えられる. 次に, 切削温度と工具摩耗の関係をより明確にするため, 切削 距離と工具摩耗量の線形関係における直線の傾き(工具摩耗率 $d W / d L)$ と切削温度の関係について実測値と計算值を比較した結 果を図 8 に示す．図 8 に示す摩耗量の計算值については, 総摩 耗量のほか, アブレシブ摩耗量と拡散摩耗量の計算值を区別し て示している. 図 7 と同様に，このグラフからも測定值と計算 值は良い一致を示しており，低速度から高速度まで全速度領域 において本モデルにより逃げ面摩耗幅を精度良く表すことがで きていることが分かる．また，低速度領域では拡散摩耗はほと んど無視できる程度となり, 式(2)の第 1 項のようにアブレシブ 摩耗を考慮する必要があることが分かる.

\section{5. 工具摩耗予測システムの開発}

実際の切削条件設計においては切削条件と工具摩耗の関係を 明らかにしておくことが重要である，そこでまず，表 4 に示す ように切削速度と送り速度を様々変化させて切削温度解析を行 い，切削条件と切削温度の関係を求めた．解析結果を図 9 に示 す.この切削温度の解析結果と式(2), 式(3), 式(4)により工具摩

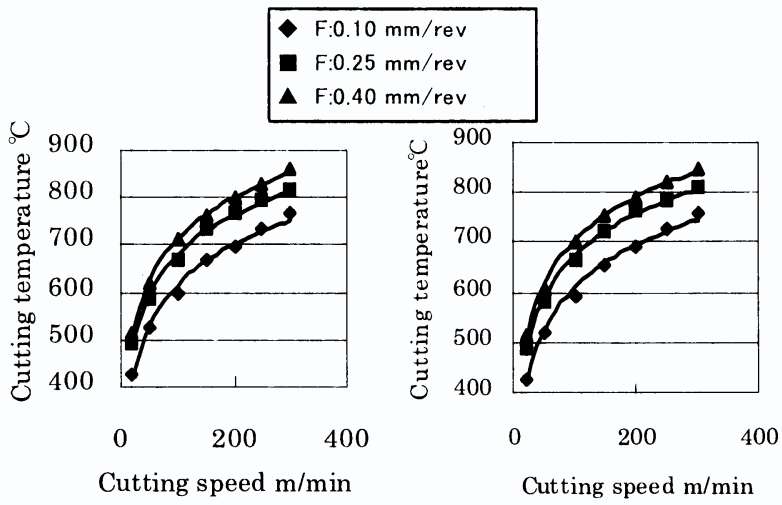

(a) $\mathrm{S} 45 \mathrm{CS} 1$

(b) $445 \mathrm{CS} 2$

Fig. 11 Relationship between cutting conditions and cutting temperature (Free cutting steel)

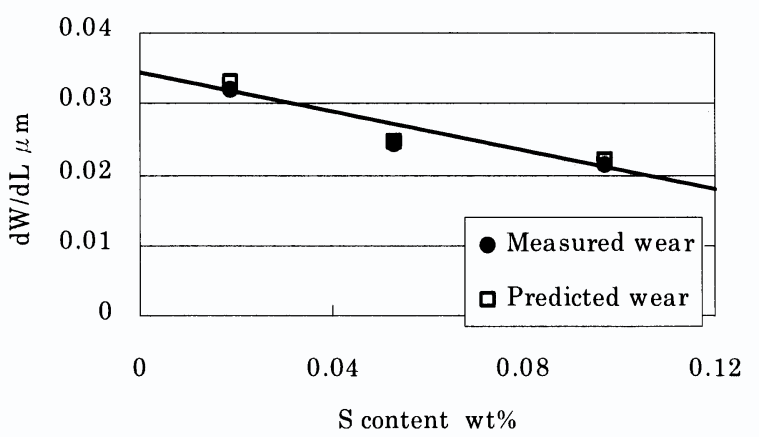

Fig. 12 Relationship between wear rates and additive amount of sulfur

耗を予測することが可能となるが，解析での切削条件以外の切 削温度については, 各送り速度における切削速度と切削温度の 回帰式を式(5), 式(6), 式(7)とし, この回帰式から解析での切削速 度条件以外の切削温度を求めた. 式中の $V$ は切削速度を示す. また, 送り速度の変化に対しては, 各送り速度における切削温 度から直線補間により求めた。

temp $=122 \cdot \log V+64.4$ (Feed rate: $0.10 \mathrm{~mm} / \mathrm{rev})$

temp $=132 \cdot \log V+83.5$ (Feed rate: $0.25 \mathrm{~mm} / \mathrm{rev}$ )

temp $=127 \cdot \log V+137$ (Feed rate: $0.40 \mathrm{~mm} / \mathrm{rev}$ )

以上により, 様々に変化する切削条件において, 工具摩耗を 計算することが可能となる．そこで，切削速度および送り速度 を変化させ，切削距離が $4000 \mathrm{~m}$ に達した時の工具摩耗量の予測 を行った結果を図 10 に示す. 図に示されるように，切削条件の 変化に対する工具摩耗の増減を容易に知ることができ，本工具 摩耗予測システムは, 切削条件設計において非常に有益である と考えられる.

次に，快削添加成分の影響について検討を行う．硫黄や鈶な どの快削元素は, 鋼材加工における被削性向上のために必要に 応じて添加される. 特に硫黄は，鋼材中で $\mathrm{Mn}$ と硫化物 $\mathrm{MnS}$ を 形成し，切りくず分断性を向上させるほか，工具摩耗を低減さ せることが知られている7).このことから, 予め硫黄の工具摩耗 低減効果を予測することができれば, 要求される工具寿命に対 し適切な硫黄添加量を求めることが可能となり，鋼材成分設計 効率化において非常に大きな効果が期待できる，そこで，硫黄 添加量と工具摩耗量の関係を定量化するため, 本工具摩耗予測 システムにより硫黄添加鋼の工具摩耗予測を行った.ここでは, 


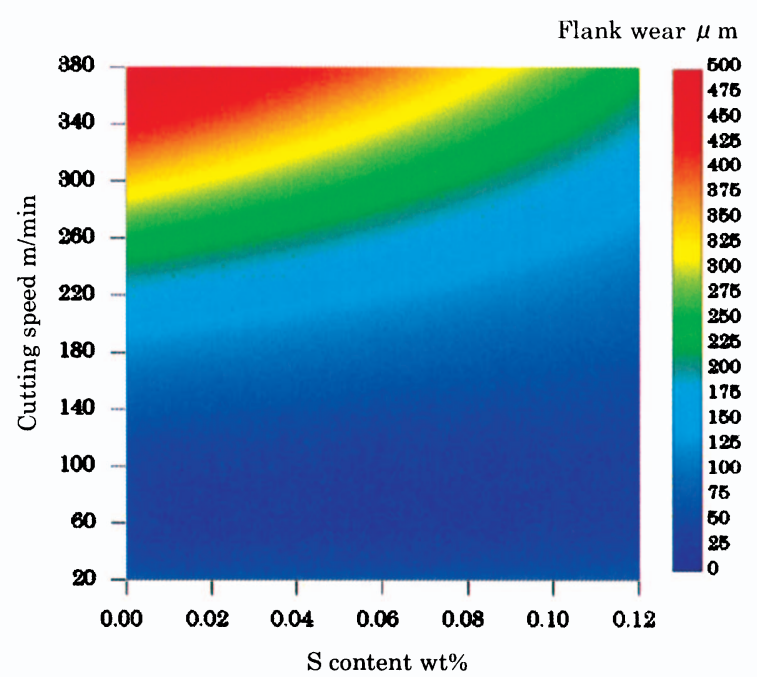

Fig. 13 Relationship between cutting speed, $S$ content and predicted flank wear (S45CS1)

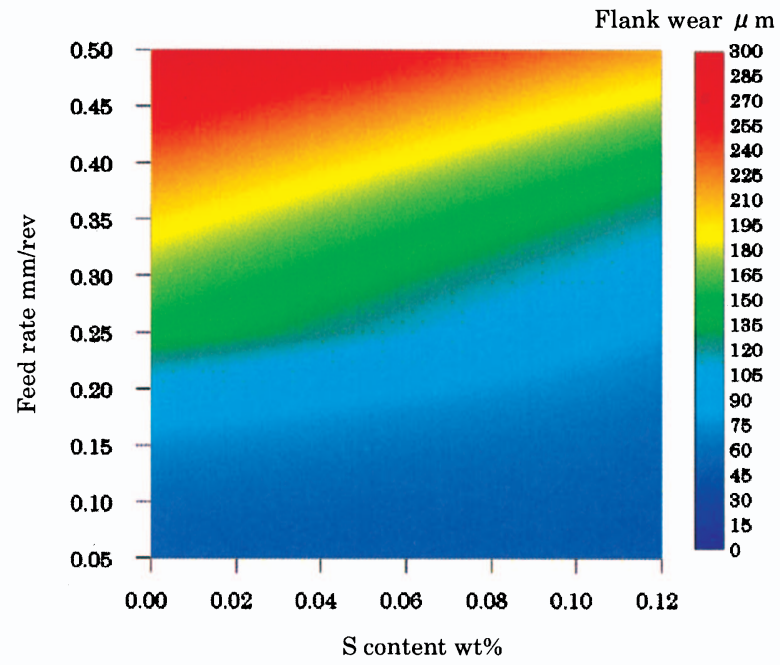

Fig. 14 Relationship between feed rate, $\mathrm{S}$ content and predicted flank wear (S45CS1)

S45C 材（硫黄 $0.019 \mathrm{wt} \%$ 添加）に, 硫黄を $0.053 \mathrm{wt} \%$ 添加した S45CS1 材と 0.097wt\%添加した S45CS2 材に対して, 表 4 に示す 切削条件で切削温度の解析を行った．解析結果を図 11 に示す. 図のように, 硫黄の添加に伴って若干温度解析値が低下してい る.これは, 硫黄添加により機械的特性が変化したためである. 例えば降伏応力では, S45Cが410MPa であるのに対し, S45CS1, S45CS2 ではそれぞれ 400MPa，395MPa と小さいため, 温度が 低下したと考えられる. 今回は鈶添加快削鋼については検討を 行っていないが, 鈶のように潤滑効果を向上させる添加物を添 加した場合は, 温度解析時に摩擦条件の詳細な検討が必要にな ると考えられる.

次に, 解析により得られた切削温度をモデル式(2)に代入して 工具摩耗の予測を行った. ここでモデル内の係数 $\mathrm{C}_{1}, \mathrm{C}_{2}, \mathrm{C}_{3}$ に ついては, 極微量の添加物が摩耗機構に与える影響は無視でき るものとして，S45C 鋼に対して同定された上述の值を用いた. また，実際に超硬 P10 種工具による加工実験を行い，それぞれ の鋼材における工具摩耗量の測定值と予測值の比較を行った. ここでは, 切削速度を $200 \mathrm{~m} / \mathrm{min}$, 送り速度を $0.25 \mathrm{~mm} / \mathrm{rev}$ とした. 各鋼材に対して測定および予測された摩耗率 $(d W / d L)$ を図 12 に示す，図に示されるように, 硫黄の添加に伴って摩耗量は小
Table 5 Cutting conditions

\begin{tabular}{l|r|r|r|r|r|r} 
& No.1 & No.2 & No.3 & No.4 & No.5 & No.6 \\
\hline Cutting speed $\mathrm{m} / \mathrm{min}$ & 100 & 350 & 200 & 200 & 170 & 140 \\
Feed rate $\mathrm{mm} / \mathrm{rev}$ & 0.25 & 0.25 & 0.05 & 0.35 & 0.35 & 0.40 \\
Depth of cut $\mathrm{mm}$ & 1.5 & 1.5 & 1.5 & 1.5 & 1.5 & 1.5 \\
Tool material & P10 & P10 & P10 & P10 & P10 & P10 \\
Workpiece material & S45CS1 & S45CS1 & S45CS1 & S45CS1 & S45CS1 & S45CS1 \\
\hline
\end{tabular}

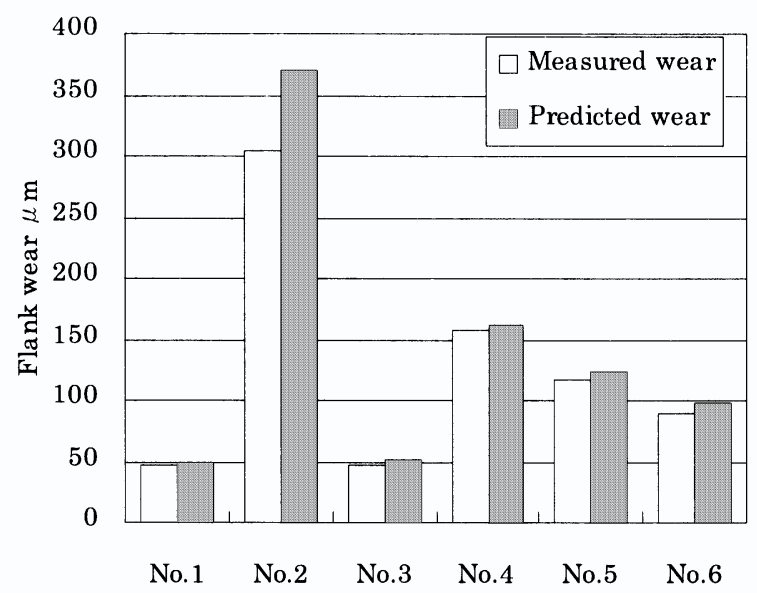

Fig. 15 Comparison between predicted and measured wear (S45CS1)

さくなる傾向があり，それぞれの硫黄添加鋼における工具摩耗 量の測定值と, S45C 材に対して同定した工具摩耗予測モデルに よる予測值は良く一致している.

ここで, 図 12 における工具摩耗予測值と硫黄添加量の関係を 1 次式で補間することにより, 特定の切削条件（切削速度 $200 \mathrm{~m} / \mathrm{min}$ 、送り速度 $0.25 \mathrm{~mm} / \mathrm{rev}$ ) において, 硫黄添加量の増減 に対する工具摩耗の変化を定式化することができる. 同様にし て, 図 10 に示す切削条件域で硫黄添加量と工具摩耗の関係を定 式化し, 切削条件および硫黄添加量を変化させた時の切削距離 4000m における工具摩耗の予測を行った. 予測結果として, 切 削速度と硫黄添加量を変化させた場合の工具摩耗量を図 13 に, 送り速度と硫黄添加量を変化させた場合の工具摩耗量を図 14 に 示す. なお, 図 13 の計算では送り速度を $0.25 \mathrm{~mm} / \mathrm{rev}$ に固定し, また図 14 では, 切削速度を $200 \mathrm{~m} / \mathrm{min}$ に固定して表示している. 図 13, 図 14 に示すように, 本摩耗予測システムにより工具摩耗 に与える硫黄添加の効果を容易に予測できるため, 鋼材成分設 計時に工具摩耗を考慮した硫黄添加量の最適設計が可能になる と考えられる.

\section{6. 工具摩耗予測システムの検証}

開発した工具摩耗予測システムの予測精度を検証するため, S45CS1 材に対して切削速度と送り速度を変化させて切削距離 $4000 \mathrm{~m}$ まで切削実験を行い, 測定值と予測值の比較を行った. 切削条件を表 5 に, 比較結果を図 15 に示す. 図のように予測值 と測定值は良い一致を示していることがわかる.

次に，本システムを利用して切削条件を最適化することを考 える. 図 16 にS45CS1 材における切削条件と工具摩耗の予測值 との関係を示す. 図中の数值は, 図 15 に示した確認実験におけ る工具摩耗の測定結果を示している.ここで, 仮に現行条件を, 図中に赤丸で示す切削速度 $200 \mathrm{~m} / \mathrm{min}$, 送り速度 $0.25 \mathrm{~mm} / \mathrm{rev}$ とす ると, 工具摩耗を増加させず, 加工効率を向上させるには, 図 中矢印の方向に切削条件を変更することが有効であると予測さ 


\section{7. 結言}

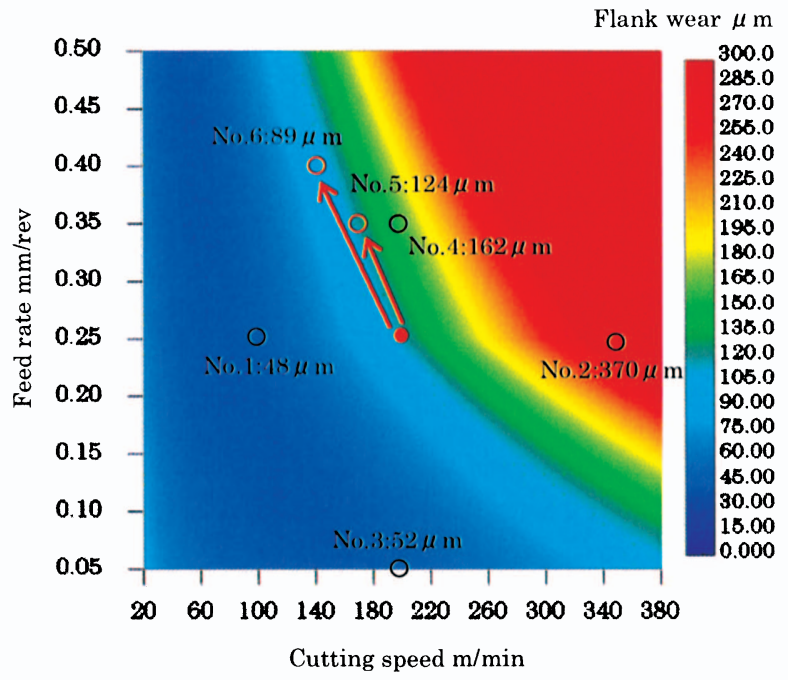

Fig. 16 Comparison between predicted and measured flank wear (S45CS1)

れる. そこで, 高効率切削条件として表 5 に示す条件 No.5, No.6 を選定すると，現行条件では摩耗量 $107 \mu \mathrm{m}$ （図 12 の摩耗率測 定における実験值) であるのに対して, 条件 No.5 では加工能率 が約 $20 \%$ 向上して摩耗量は $124 \mu \mathrm{m}$ となり, 大きく工具寿命を 低下させずに加工効率を向上させることができた．また，条件 No.6では, 加工能率が $12 \%$ 向上する上に摩耗量は $89.3 \mu \mathrm{m}$ に減 少し, 加工効率向上と工具寿命延長を両立することができた. なお, 条件 No.6 において, 同一加工除去体積となる切削距離 $2500 \mathrm{~m}$ で比較すると, 工具摩耗量の測定值は $59 \mu \mathrm{m}$ となり, 摩 耗量を $24 \%$ 減少させることができた.

これらの結果から, 本手法により加工効率を向上し, かつ工 具寿命を延長させる切削条件の選定が可能となる. すなわち, 本工具摩耗予測システムは, 切削条件の最適化や被削材の開発 を行う上で，実用的に有用であると考えられる.
本研究では, 従来の工具摩耗モデルを改良するとともに, 有限要素法解析による刃先温度の予测を組み合わせること で実用的な工具摩耗予測システムの開発を試み, 以下の成 果を得た.

(1) アブレシブ摩耗と拡散摩耗を同時に考慮することで広い加工 条件に対応し得る逃げ面摩耗予測モデルを構築した.

(2) 上記モデルにFEM切削シミュレーションにより計算さ れる切削温度, 被削材.工具の高温時の機械的特性を入力 することにより, $\mathrm{S} 45 \mathrm{C}$ 鋼の旋削加工における工具摩耗 量を広い切削速度範囲にわたって正確に表現し得ること を確認した。

(3) 硫黄添加快削鋼において, 硫黄の添加量の工具摩耗に対 する影響を補間式で表すことにより, 硫黄添加量と切削 条件の変化に対して工具摩耗量を予測することが可能 な工具摩耗予測システムを開発した。

(4) 切削実験による検証の結果, 本工具摩耗予測システムは, 広 範囲の切削条件における工具摩耗量を比較的精度良く予測 し得ることを確認した．また，本システムを利用して実際 に加工条件の改善が可能であることを示した.

\section{参 考 文 献}

1) 植松哲太郎, 大島康次郎 : 主入力変数による表見の簡潔な GMDH モ デルとその工具摩耗予測モデルへの適用, 生産研究, 33,5,(1981)28.

2) 北川武揚，前川克廣，白樫高洋，其井英治：切削工具寿命の解析的 予測に関する研究（第4 報）,精密工学会誌,53,9(1987)1414.

3）白井英治 : 現代切削理論, 共立出版, (1990)162.

4) E. Kannatery-Asibu, Jr.: A Transport-Diffusion Equation in Metal Cutting and its Application to Analysis of the Rate of Flank Wear, ASME Journal of Engineering for Industry, 107 (1985) 81.

5）生田明彦, 篠崎賢二: 切削過程における凝着現象の材料学的檢討, 高温学会誌, 32, 3 (2006) 152.

6) P. kwon, R. kountanya: Experimental Observations on Flank Wear in Machining Spherodized Plain Carbon Steels, Prepr. ASME/STLE Tribol. Conf.,(1998) 1 .

7) 鳴瀧則彦, 山根八洲男ほか: 高速切削における硫黄快削鋼の被削性, 精密丁.学会誌, 53, 3(1987) 455 . 